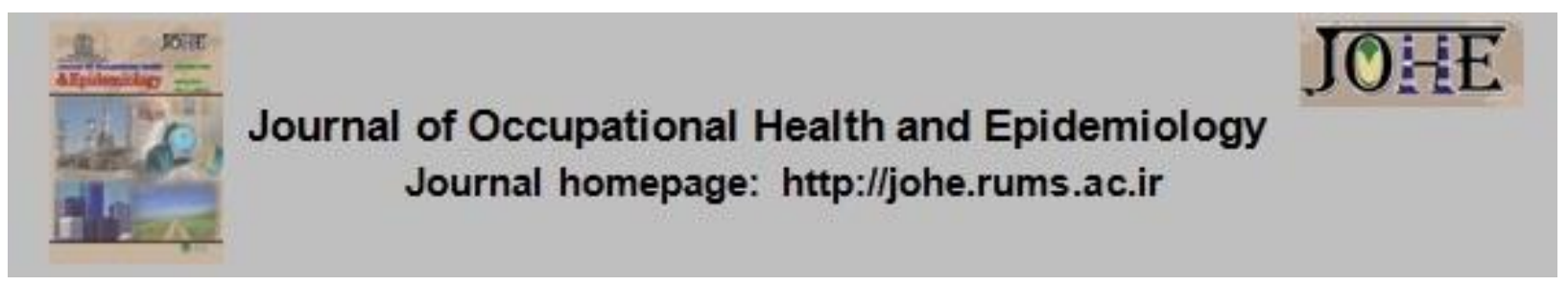

\title{
The association between musculoskeletal disorders with mental workload and occupational fatigue in the office staff of a communication service company in Tehran, Iran, in 2017
}

\author{
Behnam Haghshenas ${ }^{1}$, Ehsanollah Habibi², Fahimeh Haji Esmaeil Hajar ${ }^{3}$, Ayoub \\ Ghanbary Sartang ${ }^{1, *}$, Louis van Wijk ${ }^{4}$, Sahel Khakkar ${ }^{5}$
}

1- MSc in Occupational Health Engineering, Department of Occupational Health, School of Public Health, Isfahan University of Medical Sciences, Isfahan, Iran.

2- Professor, Department of Occupational Health Engineering, School of Health, Isfahan University of Medical Sciences, Isfahan, Iran.

3- MSc in Environmental Management, Department of Environmental Management, Islamic Azad University, Tehran, Iran.

4- BSc in Integrated Safety \& Security Management, Department of Integrated Safety \& Security Management, La Hague University, Gravenhage, Den Haag, Netherland.

5- MSc in Occupational Health Engineering, Department of Occupational Health, Shahid Beheshti University of Medical Sciences, Tehran, Iran.

\section{Article Info}

* Corresponding authors:

Ayoub Ghanbary Sartang

E-mail:

aioobghanbary@ymail.com

Article history

Received: Oct, 2017

Accepted: Jan, 2018

Print ISSN: 2251-8096

Online ISSN: 2252-0902

Peer review under responsibility of Journal of Occupational Health and Epidemiology

\begin{abstract}
Background: Musculoskeletal disorders (MSDs) are one of the most common work-related illnesses, which lead to high costs and a reduction in labor productivity. The aim of this study was to investigate the relationship between MSDs with mental workload (MWL) and occupational fatigue among the office staff of a communication service in Tehran, Iran, in 2017.

Materials and Methods: This descriptive study was conducted on 94 staff of a communication service company in June 2017. The data collection tools included Rapid Office Strain Assessment (ROSA), NASA Task Load Index (NASA-TLX) questionnaire and Swedish Occupational Fatigue Inventory (SOFI). Data analysis conducted using descriptive statistics and one-way ANOVA test in SPSS software.

Results: $73 \%$ of the participants were women with mean age of $28.25 \pm$ 3.40 years and the remaining participants were men with mean age of $26.91 \pm 4.60$ years. According to the results of the Nordic questionnaire, the highest pain was observed in the neck $(65.94 \%)$ during the last year. According to the results of the ROSA, $71 \%$ of the participants were at the warning risk level and the need for ergonomic interventions. In addition, the relationship between occupational fatigue and its subscales with MSDs was significant in all cases $(P<0.001)$. Finally According to the results, the participants' MWL was high.

Conclusions: The results of the present study showed that high workload and occupational fatigue cause MSDs, and intervention is necessary in these individuals.
\end{abstract}

Keywords: Musculoskeletal Disorders, Work Load, Fatigue

\section{Introduction}

The increasing spread of technology and knowledge in human life has increased the speed of work as well as production and productivity. However, these changes have been associated with complications such as inertia, fatigue, neuropsychiatric stress, and

(C) The Author(s) 2018. Published by Rafsanjan University of Medical Sciences Press.

All rights reserved. For permissions, please e-mail: johe.rums@gmail.com, johe@rums.ac.ir 
increasing musculoskeletal disorders (MSDs) (1). MSD is one of the most common and costly problems associated with work in all countries of the world. One of the biggest problems of occupational health in industrial and developing countries is work-related MSDs caused by poor working postures (2). Definition of these disorders includes disorders in muscles, ears, pods, peripheral nerves, joints, tendons, ligaments, and blood vessels, which can be repeated during work and doing tasks (3). MSD is a factor causing loss of working time, and increasing costs and human injuries. It is commonly found in the upper limbs including neck and waist of computer users; the main causes of this problem include duplicate fingers, hands, poor body static postures, contact pressure on the wrists, and time spent working with the computer (4-8). More than 60 percent of the administrative staff in growing countries complains about physical discomfort, many of them related to MSDs. The prevalence rate of skeletal-musculoskeletal disorders according to the type of work with computer and the duration of contact with computer workstation reported to be 15-70 percent in the developing countries $(9,10)$. Although the arrival of computer technology to developing countries is cause to speeding up work, as well as saving time, energy and resources, it had significant adverse effects on human resources and caused MSDs due to the lack of attention to physical, psychological and social characteristics. Research has shown that feeling of pain and discomfort in various parts of musculoskeletal system is the major problem in working environments, which leads to absenteeism. Moreover, these disorders lead to permanent disabilities in the staff having symptoms such as pain, anesthesia, and lethargy; and cause loss of working time, decrease in production, and increase in compensation of labor costs (11). In administrative works, these disorders gradually occur due to inappropriateness and long maintenance of some postures when performing work, as well as non-ergonomic table and chair in a long process. Therefore, it is necessary to control the risk factors of these disorders in the workplace in order to prevent the economic losses caused by these disorders and to ensure the health of workforce (12). Since the inappropriate posture during work is one of the most important risk factors for MSDs in many ways, the risk of these disorders and posture analysis should be considered as the basis for evaluation (13, 14). In the study by Evans et al., 94 percent of computer users complained of shoulder pain, and they were at risk of MSDs (15). Yektaee et al. examined the MSDs in the various parts of computer users' body, who were working in private companies and government agencies, and concluded that 75 percent of computer users occasionally felt pain in their waist, neck and legs, and 20-25 percent of them had the experience of MSDs each day (16). One of the factors affecting the performance of individuals in organizations is occupational stress and workload, which endangers the health of many of them (17). In recent decades, the issue of workload and its effects on organizations has become one of the main issues of organizational behavior. Mental workload (MWL) is one of the most widely used concepts in ergonomics and human factors, and represents a topic with increasing importance (18). Workload and occupational stress have direct relationship with person's function, and one of the factors affecting the health, is individual's safety and comfort (19). Workload is a term used to describe the amount of cognitive and physical resources that an operator uses to perform a task (20). It is a multidimensional and complex structure affected by external needs, task, environment, organization, psychological, and cognitive abilities (21). It is possible that MWL affects the physical and mental factors creating MSDs. The signs and symptoms of 
MSD include the pain and discomfort experienced in spinal cord and ends of body, which rise due to many variables and parameters such as demographic characteristics including age and gender, occupational and work environment characteristics such as force, posture and duration of work, sound and vibration, and psychological factors (22, 23). The relationship between MWL with MSDs as well as its degree of impact is estimated as a psychological factor in development of MSDs, and the results are used to understand the exact ergonomic situation of staff, and to plan the effective interventions and corrective and preventive measures. The operator's duties require numerous cognitive functions such as continuous attention and accuracy, the ability to identify appropriate vision, memory, planning and decision making due to the need for attention and concentration in humanmachine relationship and exact and timely response to regulating process systems (24, 25). The office staff of communication service companies are exposed to physical strain as an inherent part of their job; and as a consequence, are at the risk of morbidity in terms of injuries and MSDs in general. The aim of this study was to investigate the relationship between MSDs with MWL and occupational fatigue among the office staff of a communication service company in Tehran, Iran, in 2017.

\section{Material and Methods}

This descriptive study was conducted in June 2017, on 94 employees of administrative staff in a communications service company in Tehran City. The sample size was determined with $95 \%$ confidence level and absolute error value of $25 \%$ for about 94 people. The subjects were selected through simple random sampling. Inclusion criteria were at least one-year work experience and at least 8 hours of work with computer per day. The exclusion criteria were pain or discomfort in various organs of body. Written consent forms were obtained from all those who accepted to participate in the study after receiving details about the study methods and objectives. After evaluating the administrative jobs in analyzed work environment, a random selection of employees was done according to the inclusion and exclusion criteria. At first, demographic information questionnaire including age, gender, work experience, weight, height, and body mass index (BMI) was completed by the participants. Then a standard Nordic questionnaire, which is a self-report questionnaire for assessing MSDs in neck, shoulders, back, waist, elbows, wrists, hands, thighs, knees and feet was distributed among the participants. According to Nordic questionnaire, the respondents should identify which part of their body (neck, shoulders, elbows, arms/wrists, back, lumbar, thigh/hips, knees, legs/ankles) had been distressed during the last 12 months. Subsequently, they should determine whether the problem was causing them to be unable to work properly (24). In addition, NASA Task Load Index (NASA-TLX) questionnaire was used to evaluate the participants' MWL (26). The NASA-TLX divides the entire workload into six subscales including mental need, physical need, time requirement, performance, effort, and frustration, which is used as the first part of an indicator. The validity and reliability of this indicator was confirmed by the study of Qorbani et al (27). Rapid office strain assessment (ROSA) method is based on standard EN-ISO 9241:1997. ROSA method is an observation method that can identify ergonomic risk factors, and has good reliability for the assessment of MSDs. This method involves three main steps including, scores determined.in sections of chairs, monitor, telephone, mouse, and keyboard, and scores related to duration of use in a day. According to the scores obtained in this 
section and putting them in the final table, ROSA final score is determined, which is in the range of 0 to 10 . Scores of 0 to 3 represent low risk rate, 3 to 5 is area of notification, and scores more than 5 need ergonomic intervention (28-30). Finally, for assessing occupational fatigue, Swedish Occupational Fatigue Inventory (SOFI), designed by Ahsberg et al. in 1997, was used for the purpose of subjective evaluation of work-related fatigue. This questionnaire can assess psychological and physical aspects (31). Several studies on the different versions of SOFI considered it as a reliable tool (32). Soltaniyan et al. studied the reliability and validity of 20 Persian language fact sheets of SOFI questionnaire. In this study, an exploratory factor analysis and Cronbach's alpha method were used to find out the validity and reliability of appropriate version (33, 34). Finally, Data analysis was conducted using descriptive statistics and one-way ANOVA test in SPSS software (version 19, SPSS Inc., Chicago, IL, USA). The value of $\mathrm{P}<0.05$ was considered statistically significant.

\section{Results}

In this study, 94 people participated including 69 women (73\%) with an average age of $28.35 \pm 3.40$ years, and 25 men $(27 \%)$ with an average age of $26.91 \pm 4.60$ years, who were administrative staff of a communication service company. Demographic characteristics of age, work experience, and BMI are shown in table 1.

Table 1: Demographic variables of the administrative staff of a communication service company in Tehran City, Iran, in 2017

\begin{tabular}{|c|c|c|c|}
\hline \multirow{2}{*}{\multicolumn{2}{|c|}{ Variable }} & \multicolumn{2}{|c|}{ Gender } \\
\hline & & Women & Men \\
\hline \multicolumn{2}{|c|}{ Number } & 69 & 25 \\
\hline \multicolumn{2}{|c|}{ Age average (Year) } & $28.35 \pm 3.40$ & $26.91 \pm 4.60$ \\
\hline \multirow{3}{*}{$\begin{array}{c}\text { BMI average }\left(\mathrm{kg} / \mathrm{m}^{2)}\right) \mathrm{n} \\
(\%)\end{array}$} & normal & $62(89.85)$ & $13(52.00)$ \\
\hline & Overweight & $5(7.20)$ & $9(36.00)$ \\
\hline & Fat & $2(2.95)$ & $3(12.00)$ \\
\hline \multicolumn{2}{|c|}{ Average of working hours } & \multicolumn{2}{|c|}{8} \\
\hline \multirow[b]{2}{*}{ Level of Education } & Bachelor $\mathrm{n}(\%)$ & $48(69.00)$ & $17(68.00)$ \\
\hline & $\begin{array}{c}\text { Less than a bachelor's degree } \\
n(\%)\end{array}$ & $21(31.00)$ & $8(32.00)$ \\
\hline Average of work & $1-3 \mathrm{n}(\%)$ & $53(76.81)$ & $19(76.00)$ \\
\hline experience (years) & More than $3 \mathrm{n}(\%)$ & $16(23.19)$ & $6(24.00)$ \\
\hline \multicolumn{2}{|c|}{ Type of work activity } & \multicolumn{2}{|c|}{ Permanent sitting } \\
\hline
\end{tabular}

* BMI: Body mass index

According to the results of the Nordic questionnaire (Table 2), the highest MSDs and discomfort among the participants during the last year was in neck (65.94\%) and knees (60.63\%), and the least amount of MSDs was in back (15.55\%). At least 15 participants and at most 62 participants have experienced pain in one of their organs with symptoms of MSD during the past 12 months. The results of ROSA method showed that 27 people (29.25\%) were in the area of low risk and had score less than 3, 43 people (45.8\%) were in the warning zone having score between 3 to 5, and 24 people $(24 \%)$ were in the area of high risk, having scores more than 5 who needed ergonomic interventions in place. In addition, the average score of ROSA method was 5.1, showing that the individuals were in warning zone and needed precaution. 
Table 2: The prevalence of musculoskeletal disorders (MSDs) in different organs of body in the administrative staff of a communication service company in Tehran City, Iran, in 2017

\begin{tabular}{ccc}
\hline Variable & $\begin{array}{c}\text { In last 12 months } \\
\mathbf{n}(\%)\end{array}$ & $\begin{array}{c}\text { In last 7 days } \\
\mathbf{n}(\%)\end{array}$ \\
\hline Neck & $62(65.94)$ & $55(58.51)$ \\
\hline Shoulder & $49(52.12)$ & $41(43.61)$ \\
\hline Elbow & $19(20.21)$ & $13(13.82)$ \\
\hline Hands and wrists & $44(46.80)$ & $33(35.10)$ \\
\hline Hips and thighs & $45(47.87)$ & $36(38.29)$ \\
\hline knees & $57(60.63)$ & $49(52.12)$ \\
\hline Waist & $25(26.59)$ & $22(23.40)$ \\
\hline Ankles & $37(39.36)$ & $28(29.78)$ \\
\hline Backside & $15(15.95)$ & $9(9.57)$ \\
\hline
\end{tabular}

According to table 3, one-way ANOVA test showed that there was a significant difference between the scores obtained from ROSA method and the prevalence of MSDs ( $P<0.0001)$; in addition, MSD in women was more than in men.

Table 3: Results obtained from rapid office strain assessment (ROSA) for administrative staff of a communication service company in Tehran City, Iran, in 2017

\begin{tabular}{|c|c|c|c|c|c|c|}
\hline \multicolumn{7}{|c|}{ ROSA final score } \\
\hline Variable & Classification & $\begin{array}{c}\text { Rating less } \\
\text { than } 3 \\
\text { (Percent) }\end{array}$ & $\begin{array}{c}\text { Ratings } \\
\text { between } 3 \\
\text { to } 5 \\
\text { (Percent) }\end{array}$ & $\begin{array}{c}\text { Raring } \\
\text { more than } \\
5 \\
\text { (Percent) }\end{array}$ & $\begin{array}{c}\text { Average } \\
\text { rating of } \\
\text { ROSA }\end{array}$ & $\mathbf{P}^{\star}$ \\
\hline \multicolumn{2}{|c|}{ Average raw score } & 29.2 & 45.8 & 24.9 & $2.25 \pm 5.10$ & $P<0.0001$ \\
\hline \multirow{2}{*}{ Gender } & Women & 30.2 & 34.5 & 35.3 & $5.40 \pm 1.90$ & \multirow{2}{*}{$P<0.0001$} \\
\hline & Men & 28.3 & 57.1 & 14.6 & $4.80 \pm 2.60$ & \\
\hline \multirow{3}{*}{$B M I^{\star *}$} & Normal & 32.4 & 44.8 & 22.8 & $5.10 \pm 1.08$ & \multirow{3}{*}{$P<0.0001$} \\
\hline & Overweight & 33.2 & 36.4 & 30.4 & $4.90 \pm 1.69$ & \\
\hline & Fat & 29.7 & 31.6 & 38.7 & $5.20 \pm 1.96$ & \\
\hline \multirow[b]{2}{*}{$\begin{array}{c}\text { Level of } \\
\text { education }\end{array}$} & Bachelor & 27.9 & 47.9 & 24.2 & $4.70 \pm 1.39$ & \multirow[b]{2}{*}{$P<0.0001$} \\
\hline & $\begin{array}{l}\text { Less than a } \\
\text { bachelor's } \\
\text { degree }\end{array}$ & 24.5 & 44.6 & 30.9 & $5.10 \pm 1.96$ & \\
\hline \multirow{2}{*}{$\begin{array}{c}\text { Work } \\
\text { experience }\end{array}$} & $\begin{array}{l}\text { Between } 1 \\
\text { and } 3 \text { years }\end{array}$ & 26.6 & 49.1 & 24.3 & $4.90 \pm 1.97$ & \multirow{2}{*}{$P<0.0001$} \\
\hline & $\begin{array}{c}\text { More than } 3 \\
\text { years }\end{array}$ & 28.8 & 39.4 & 31.8 & $2.18 \pm 5.30$ & \\
\hline
\end{tabular}

* $\mathrm{P}$-value $<0.05$ is significant relationship

${ }^{* *}$ BMl: Body mass index

According to the results obtained from NASA-TLX questionnaire, participants' workload was high (Table 4).

Finally, ANOVA test showed a significant association between MWL and MSDs ( $P<$ 0.0001). The result obtained from the evaluation of occupational fatigue questionnaire is shown in table 5, according to which there was a significant relationship between occupational fatigue and MSDs ( $P$ $<0.0001)$. 
Table 4: Average results of the six-subscales and total NASA Task Load Index (NASA-TLX) for assessing workload in the administrative staff of a communication service company in Tehran City, Iran, in 2017

\begin{tabular}{ccccc}
\hline Mental workload scales & $\begin{array}{c}\text { Total } \\
\text { Mean (SD) }\end{array}$ & $\begin{array}{c}\text { Disorders } \\
\text { (62 cases) } \\
\text { Mean (SD) }\end{array}$ & $\begin{array}{c}\text { No disorders } \\
\text { (32 people) } \\
\text { Mean (SD) }\end{array}$ & $\mathbf{P}^{* *}$ \\
\hline Mental pressure & $79.27(17.25)$ & $86.22(13.22)$ & $72.32(16.68)$ & $\mathrm{P}<0.0001$ \\
\hline Physical pressure & $40.81(24.26)$ & $49.36(21.23)$ & $32.26(24.25)$ & $\mathrm{P}<0.0001$ \\
\hline Time pressure & $68.46(18.34)$ & $79.25(19.33)$ & $57.68(24.23)$ & $\mathrm{P}<0.0001$ \\
\hline Efficiency & $40.77(27.24)$ & $44.23(22.63)$ & $37.32(26.65)$ & $\mathrm{P}<0.0001$ \\
\hline attempt and effort & $65.00(16.65)$ & $77.65(18.21)$ & $52.35(20.84)$ & $\mathrm{P}<0.0001$ \\
\hline Disappointment and frustration & $35.44(24.23)$ & $41.22(22.29)$ & $29.66(24.39)$ & $\mathrm{P}<0.0001$ \\
\hline The overall workload score & $55.85(22.86)$ & $63.14(21.23)$ & $48.56(23.66)$ & $\mathrm{P}<0.0001$ \\
\hline
\end{tabular}

* SD: Standard deviation

** P-value $<0.05$ is significant relationship

Table 5: The results of Swedish Occupational Fatigue Index (SOFI) for assessing occupational Fatigue in the administrative staff of a communication service company in Tehran City, Iran, in 2017

\begin{tabular}{|c|c|c|c|c|c|c|}
\hline Row & $\begin{array}{l}\text { Dimensions of } \\
\text { questionnaire }\end{array}$ & Factor loads & $\begin{array}{c}\text { Total } \\
\text { (94 people) } \\
\text { Mean (SD) }\end{array}$ & $\begin{array}{l}\text { Disorders } \\
\text { (62 cases) } \\
\text { Mean (SD) }\end{array}$ & $\begin{array}{l}\text { No disorders } \\
\text { (32 people) } \\
\text { Mean (SD) }\end{array}$ & $\mathbf{P}$ \\
\hline \multirow{4}{*}{1} & \multirow{4}{*}{ Lack of energy } & $\begin{array}{l}\text { Analysis and } \\
\text { exhaustion }\end{array}$ & $3.46(0.49)$ & $3.46(0.49)$ & $2.35(0.47)$ & $P<0.0001$ \\
\hline & & $\begin{array}{c}\text { Getting out of } \\
\text { energy }\end{array}$ & $3.39(0.27)$ & $4.39(0.26)$ & $2.39(0.34)$ & $P<0.0001$ \\
\hline & & Impatient & $2.80(0.64)$ & $3.80(0.78)$ & $1.80(0.98)$ & $P<0.0001$ \\
\hline & & Too worked & $1.66(1.12)$ & $2.32(0.99)$ & $1.01(0.68)$ & $\mathrm{P}<0.0001$ \\
\hline \multirow{4}{*}{2} & \multirow{4}{*}{ Physical effort } & heart beat & $0.96(0.43)$ & $1.02(0.76)$ & $0.91(0.54)$ & $P<0.0001$ \\
\hline & & Sweating & $2.42(0.52)$ & $2.71(0.35)$ & $2.13(0.44)$ & $P<0.0001$ \\
\hline & & Breathe out & $0.65(0.29)$ & $0.72(0.26)$ & $0.59(0.33)$ & $P<0.0001$ \\
\hline & & Heavy breathing & $2.01(0.66)$ & $2.26(0.69)$ & $1.77(0.78)$ & $P<0.0001$ \\
\hline \multirow{4}{*}{3} & \multirow{4}{*}{$\begin{array}{l}\text { Physical } \\
\text { discomfort }\end{array}$} & $\begin{array}{l}\text { Having muscular } \\
\text { contractions and } \\
\text { under pressure }\end{array}$ & $3.75(0.68)$ & $4.36(0.74)$ & $3.14(0.81)$ & $P<0.0001$ \\
\hline & & Numb & $2.78(0.72)$ & $3.35(0.69)$ & $2.22(0.72)$ & $P<0.0001$ \\
\hline & & $\begin{array}{l}\text { Having irreparable } \\
\text { joints }\end{array}$ & $3.63(0.55)$ & $4.21(0.45)$ & $3.05(0.63)$ & $P<0.0001$ \\
\hline & & $\begin{array}{c}\text { Having muscle } \\
\text { aches }\end{array}$ & $4.34(0.78)$ & $5.49(0.58)$ & $3.20(0.99)$ & $P<0.0001$ \\
\hline \multirow{4}{*}{4} & \multirow{4}{*}{$\begin{array}{l}\text { Lack of } \\
\text { motivation }\end{array}$} & $\begin{array}{c}\text { Carefree and } \\
\text { without worries }\end{array}$ & $0.31(0.11)$ & $0.36(0.13)$ & $0.27(0.02)$ & $P<0.0001$ \\
\hline & & Passivity & $0.36(0.14)$ & $0.44(0.18)$ & $0.29(0.08)$ & $P<0.0001$ \\
\hline & & Indifferent & $0.26(0.10)$ & $0.26(0.09)$ & $0.19(0.01)$ & $\mathrm{P}<0.0001$ \\
\hline & & Uninterested & $1.24(0.27)$ & $1.24(0.37)$ & $1.13(0.23)$ & $P<0.0001$ \\
\hline \multirow{4}{*}{5} & & $\begin{array}{c}\text { Sleep while } \\
\text { working }\end{array}$ & $0.22(0.03)$ & $0.19(0.06)$ & $0.14(0.01)$ & $P<0.0001$ \\
\hline & Drowsiness & Yawning & $1.21(0.51)$ & $1.46(0.71)$ & $0.97(0.48)$ & $P<0.0001$ \\
\hline & & Lethargy & $1.24(0.71)$ & $1.44(0.69)$ & $1.05(0.71)$ & $P<0.0001$ \\
\hline & & Sleepy & $1.14(0.41)$ & $1.32(0.61)$ & $0.96(0.54)$ & $P<0.0001$ \\
\hline 6 & $\begin{array}{c}\text { Swedish } \\
\text { Occupational } \\
\text { Fatigue Index } \\
\text { (SOFI) }\end{array}$ & \multicolumn{4}{|c|}{ Musculoskeletal Disorders Nordic questionnaire } & $P<0.0001$ \\
\hline
\end{tabular}

* SD: Standard Deviation 


\section{Discussion}

Nowadays, various MSDs occur among the people of different occupations and populations. Although these disorders occur in various parts of the body such as neck, arm, wrist, and waist, low back pain is more prevalent. According to the results, the prevalence of MSDs in the participants was higher in neck, knees, shoulders, arms, wrists and ankles during 12 past months, while it was lower in the limbs, low back, elbows, and back. Rahimabadi et al. reported that at least 76 percent of subjects had MSDs in the last 12 months that confirmed the findings of the present study (35).

Motamedzadeh et al. investigated MSDs through muscle fatigue assessment and concluded that MSD was more prevalent in the neck and shoulders in comparison to the other parts of the body, which is consistent with the results of this study (36). Chobineh et al. also reported a higher prevalence of symptoms of MSDs in the neck, backside and back of the administrative staff compared to the general population that confirmed the findings of the present study (37).

The findings of ROSA survey showed that about 71 percent of the subjects needed ergonomic interventions. In addition, the findings indicated that the prevalence of MSDs in women is more than in men. Naderi et al. in the study of MSDs assessment concluded that women have more MSDs than men that confirmed the findings of the present study (38).

The results of Nordic questionnaire and ROSA method showed that the most MSDs were related to neck shoulders, back, thighs, hips, knees, wrists, and legs. In a study by Roshani et al., it was concluded that the prevalence of MSDs was higher especially in the regions of lower back, shoulder, and neck that is in consistency with the findings of the present study (39). There was also a significant relationship between MWL and MSDs, which is consistent with the results of the study by Darvishi et al. (40). The results of this study showed a direct relationship between work experience with MSDs and increasing MWL, which is consistent with the results of the study by Ganbari et al. (41). Finally, there was a significant relationship between occupational fatigue and MSDs, and the results compared with the previous studies showed that occupational stress and occupational fatigue can be effective in MSDs, which is consistent with the results of the study by Arellano et al. (3). Habibi et al. concluded that there is a significant relationship between MSDs and the dimensions of workload frustration, total workload, temporal demand, effort, and physical demand that confirmed the findings of the present study (42). Bos et al. reported that with decrease in occupational fatigue, the amount of MSDs also decreased (43). Ando et al. concluded that there was a significant difference between MSDs and items related to work postures and workload, which confirms the results of this study (44). Sirge et al. investigated MSD symptoms and perceived fatigue in supermarket cashiers, and concluded that musculoskeletal symptoms in lower back region, neck, knee, and shoulder are significantly related to occupational fatigue, which is consistent with the results of this study (45).

The limitation of this study was the lack of opportunity to utilize a larger sample size.

\section{Conclusion}

The results of this study showed that MWL, occupational fatigue and MSDs are considerably high among communication service personnel. Moreover, the results showed that high workload and occupational fatigue cause MSDs, and intervention should be used in this individuals including redesigning computer workstation, educating users about 
ergonomic principles of working with computer, reducing working hours, developing the cycle of rest-work, and using holder papers to minimize the pressure on the neck and back and also reduce muscular and visual fatigue.

\section{Acknowledgments}

Authors of this article are obliged to acknowledge all the individuals who have been involved in this project and Paya Services Company.

\section{Conflict of interest: None declared.}

\section{References}

1. Mirmohammadi SJ, Mehrparvar $\mathrm{AH}$, Soleimani H, Lotfi MH, Akbari H, Heidari N. Musculoskeletal disorders among video display terminal (VDT) workers comparing with other office workers. Iran Occupational Health 2010; 7(2):11-4.

2. Coluci MZ, Alexandre NM, de Freitas Pedrini T. Musculoskeletal symptoms and workers' perception about job factors in a pulp and paper industry. Work 2012; 41(Suppl 1):5728-30.

3. Hernandez Arellano JL, Castillo Martinez JA, Serratos Perez JN, Garcia Alcaraz JL. Relationship between workload and fatigue among Mexican assembly operators. Int $\mathrm{J}$ Phys Med Rehabil 2015; 3(6):1-6.

4. Ferasati $F$, Sohrabi MS, Jalilian $M$. Evaluation of WMSDs in VDT users with Rapid Office Strain Assessment (ROSA) method. Journal of Ergonomics 2014; 1(3):65-74.

5. Hales TR, Sauter SL, Peterson MR, Fine LJ, Putz-Anderson V, Schleifer LR, et al. Musculoskeletal disorders among visual display terminal users in a telecommunications company. Ergonomics 1994; 37(10):1603-21.

6. Mehta RK, Agnew MJ. Influence of mental workload on muscle endurance, fatigue, and recovery during intermittent static work. Eur J Appl Physiol 2012; 112(8):2891-902.

7. Azari GR, Davuian-Talab AH. Comparison of burnout and musculoskeletal disorders among computer users and office workers. Archives of Rehabilitation 2012; 12(Supplementary 4):38-46.
8. Haukka E, Leino-Arjas $P$, Viikari-Juntura $E$, Takala EP, Malmivaara A, Hopsu L, et al. A randomised controlled trial on whether a participatory ergonomics intervention could prevent musculoskeletal disorders. Occup Environ Med 2008; 65(12):849-56.

9. Robertson MM, Ciriello VM, Garabet AM. Office ergonomics training and a sit-stand workstation: effects on musculoskeletal and visual symptoms and performance of office workers. Appl Ergon 2013; 44(1):73-85.

10. Armstrong TJ, Buckle P, Fine LJ, Hagberg $M$, Jonsson B, Kilbom A, et al. A conceptual model for work-related neck and upper-limb musculoskeletal disorders. Scand J Work Environ Health 1993; 19(2):73-84.

11. Hakala PT, Rimpelä AH, Saarni LA, Salminen JJ. Frequent computer-related activities increase the risk of neck-shoulder and low back pain in adolescents. Eur $\mathrm{J}$ Public Health 2006; 16(5):536-41.

12. Choobineh A, Solaymani E, Mohammad Beigi A. Musculoskeletal symptoms among workers of metalStructure manufacturing industry in Shiraz, 2005. Iranian Journal of Epidemiology 2009; 5(3):35-43.

13. Delisle $A$, Larivière $C$, Plamondon $A$, Imbeau D. Comparison of three computer office workstations offering forearm support: impact on upper limb posture and muscle activation. Ergonomics 2006; 49(2):139-60.

14. Fisher T, Gibson T. A measure of university employees' exposure to risk factors for workrelated musculoskeletal disorders. Workplace Health Saf 2008; 56(3):107-14.

15. Evans O, Patterson K. Predictors of neck and shoulder pain in non-secretarial computer users. Int J Ind Ergon 2000; 26(3):357-65.

16. Yektaei T, Tabatabaei- Ghomsheh F, Piri L. The effect of ergonomic principles education on musculoskeletal disorders among computer users. Archives of Rehabilitation 2013; 13(4):108-16.

17. Holmes S. Work-related stress: a brief review. J R Soc Promot Health 2001; 121(4):230-5.

18. Lundberg U, Frankenhaeuser M. Stress and workload of men and women in high-ranking positions. J Occup Health Psychol 1999; $4(2): 142-51$.

19. Sveinsdottir $H$, Biering $P$, Ramel $A$. Occupational stress, job satisfaction, and working environment among Icelandic nurses: a cross-sectional questionnaire survey. Int J Nurs Stud 2006; 43(7):875-89.

20. Backs RW, Ryan AM, Wilson GF. Psychophysiological measures of workload 
during continuous manual performance. Hum Factors 1994; 36(3):514-31.

21. Weinger MB, Reddy SB, Slagle JM. Multiple measures of anesthesia workload during teaching and nonteaching cases. Anesth Analg 2004; 98(5):1419-25.

22. Mohammadi M, Mazloumi A, Nasl Seraji J, Zeraati $H$. Designing questionnaire of assessing mental workload and determine its validity and reliability among ICUs nurses in one of the TUMS's hospitals. Scientific Journal of School of Public Health and Institute of Public Health Research 2013; 11(2):87-96.

23. Cho CY, Hwang YS, Cherng RJ. Musculoskeletal symptoms and associated risk factors among office workers with high workload computer use. J Manipulative Physiol Ther 2012; 35(7):534-40.

24. Kuorinka I, Jonsson B, Kilbom A, Vinterberg $H$, Biering-Sørensen $F$, Andersson $G$, et al. Standardised nordic questionnaires for the analysis of musculoskeletal symptoms. Appl Ergon 1987; 18(3):233-7.

25. Saremi M, Fallah MR. Subjective fatigue and medical errors among nurses in an educational hospital. Iran Occupational Health 2013; 10(4):1-8.

26. So-Kum Tang $\mathrm{C}$, Au WT, Schwarzer R, Schmitz G. Mental health outcomes of job stress among Chinese teachers: role of stress resource factors and burnout. J Organ Behav 2001; 12(8):887-901.

27. Borg MG, Riding RJ, Falzon JM. Stress in teaching: a study of occupational stress and its determinants, job satisfaction and career commitment among primary schoolteachers. Educ Psychol (Lond) 1991; 11(1):59-75.

28. Ghanbary-Sartang A, Habibi H. Evaluation of musculoskeletal disorders to method Rapid Office Strain Assessment (ROSA) in computers users. Journal of Preventive Medicine 2015; 2(1):47-54.

29. Sonne M, Villalta DL, Andrews DM. Development and evaluation of an office ergonomic risk checklist: ROSA-- rapid office strain assessment. Appl Ergon 2012; 43(1):98-108.

30. Mirmohammadi SJ, Mehrparvar $\mathrm{AH}$, Soleimani $\mathrm{H}$, Lotfi $\mathrm{MH}$, Akbari $\mathrm{H}$, Heidari $\mathrm{N}$. Musculoskeletal disorders among video display terminal (VDT) workers comparing with other office workers. Iran Occup Health 2010; 7(2):11-4.

31. Winwood PC, Winefield AH, Dawson D, Lushington K. Development and validation of a scale to measure work-related fatigue and recovery: the Occupational Fatigue
Exhaustion/Recovery Scale (OFER). J Occup Environ Med 2005; 47(6):594-606.

32. Barker LM, Nussbaum MA. Fatigue, performance and the work environment: a survey of registered nurses. J Adv Nurs $2011 ; 67(6): 1370-82$.

33. Sultanian AR, Motamedzade Torghabe M, Shafii Motlagh M, Garkaz A, Mahdavi N. Persian version of Swedish Occupational Fatigue Inventory (P-SOFI): validity and reliability. Iran Occupational Health 2014; 11(1):34-43.

34. Javadpour F, Keshavarzi S, Choobineh A, Aghabaigi M. Validity and reliability of the Swedish Occupational Fatigue Inventory (SOFI-20) among Iranian working population. Journal of Ergonomics 2015; 3(1):50-8.

35. Rahimabadi S, Khanjani $\mathrm{N}$, Mardi $\mathrm{H}$. The prevalence of musculoskeletal disorders and their related factors in workers of a dairy factory, Nishabur, Iran. Journal of Health Development 2012; 1(2):121-9.

36. Motamedzade M, Saedpanah K, Salimi K, Eskandari T. Risk assessment of musculoskeletal disorders by Muscle Fatigue Assessment method and implementation of an ergonomic intervention in Assembly industry. Journal of Occupational Hygiene Engineering 2016; 3(1):33-40

37. Choobineh $A R$, Rahimi Fard $H$, Jahangiri $M$, Mahmood Khani S. Musculoskeletal injuries and their associated risk factors. Iran Occupational Health 2012; 8(4):70-81.

38. Nadri H, Nadri A, Khanjani N, Nadri F, Jafari Roodbandi A. Evaluating the factors effective on musculoskeletal disorders among the employees of one of Qazvin's governmental offices. Journal of Health and Development 2013; 2(2):106-16.

39. Rowshani Z, Mortazavi SB, Khavanin A, Mirzaei R, Mohseni M. Comparing RULA and Strain index methods for the assessment of the potential causes of musculoskeletal disorders in the upper extremity in an electronic company in Tehran. Feyz 2013; 17(1):61-70.

40. Darvishi E, Maleki A, Giahi O, Akbarzadeh A. Subjective mental workload and its correlation with musculoskeletal disorders in bank staff. J Manipulative and Physiol Ther 2016; 39(6):420-6.

41. Habibi E, Mohammadi Z, Ghanbary Sartang A. Ergonomic assessment of musculoskeletal disorders risk among the computer users by Rapid Upper Limb Assessment method. Int $\mathrm{J}$ Environ Health Eng 2016; 5(1):15. 
42. Habibi E, Taheri MR, Hasanzadeh A. Relationship between mental workload and musculoskeletal disorders among Alzahra Hospital nurses. Iran J Nurs Midwifery Res 2015; 20(1):1-6.

43. Bos EH, Krol B, Van Der Star A, Groothoff JW. The effects of occupational interventions on reduction of musculoskeletal symptoms in the nursing profession. Ergonomics 2006; 49(7):706-23.
44. Ando S, Ono Y, Shimaoka M, Hiruta S, Hattori $Y$, Hori $F$, et al. Associations of selfestimated workloads with musculoskeletal symptoms among hospital nurses. Occup Environ Med 2000; 57(3):211-6.

45. Sirge T, Ereline J, Kums T, Gapeyeva H, Pääsuke M. Musculoskeletal symptoms, and perceived fatigue and work characteristics in supermarket cashiers. Agronomy Research 2014; 12(3):915-24. 